\author{
Agnieszka Turska-Kawa \\ University of Silesia (Poland) \\ ORCID: https://orcid.org/0000-0002-2748-7037 \\ e-mail: agnieszka.turska-kawa@us.edu.pl
}

\title{
Religious Determinants of Socio-Political Openness of Young Silesians in Poland
}

\begin{abstract}
The aim of the presented study was to diagnose the role of religious engagement in the social attitudes of young Silesians, operationalized on the continuum of closeness vs. openness in three areas: (1) community engagement, (2) approval for religion's interference in the public space, and (3) accepting Catholic Church hierarchs' views on problems such as euthanasia, artificial contraception, homosexual relationships and in vitro fertilization. The group defined in the presented study is young (age: 16-19) Silesians from Śląskie (Silesian) Province, for whom religion is one of the fundamental values and is regarded by scholars as the core of their identity $(\mathrm{N}=567)$. The results of the study confirm that religious engagement is a significant predictor of a closed social attitude in two out of three areas proposed in the model. Higher religious engagement promotes the desire to incorporate the approved religious principles into the secular space. Religious engagement is also a significant predictor of acceptance of Catholic Church hierarchs' views on underlined problems. The analysis did not show any significant relationships between religious engagement in community engagement of young Silesians.
\end{abstract}

Keywords: religiosity in Poland, religious engagement, community engagement, young Silesians

\section{Introduction}

Religiosity in Poland has a special character, resulting from over 1,000 years of bond between religion and the state, but also from modern events (Turska-Kawa, Wojtasik, 2017A), such as (1) almost five decades of communism in the $20^{\text {th }}$ century history of Poland, when the USSR enforced a totalitarian political system eradicating religion from the public sphere; (2) the appointment of cardinal Karol Wojtyła as the pope John Paul II in 1978; and system transformation in which the Church played a special role, supporting democratic opposition circles and being an active intermediary of establishing all the stages and the course of democratization processes. The country's history and natural social influences in the period 
of formation of the state have led to the development of a relatively homogeneous religious and national social structure in Poland, which is nowadays more and more often disproved by research (CBOS, 2012; CBOS, 2015B; Mariański, 2013; Turska-Kawa, Wojtasik, 2017B).

Exploring the subject of the paper is determined, i.a., by the results of research on the motivational factor of religious engagement ${ }^{1}$. Researchers agree that religion plays a significant motivational role in the social sphere, but the conclusions from the research are twofold. On the one hand, the analyses prove that religious engagement strengthens social and communal competence. Research results show that religion mobilizes people to engage in social and political activity, determining their involvement and ways of its expression (Musick, Wilson 2008: 279; Aghazadeh, Mahmoudoghli 2017). Others, however, stress that religious activity may reduce the level of social openness and social and political engagement (Turska-Kawa, Wojtasik, 2014, pp. 6-23; Storm, 2015, pp. 14-29; MarszałekKawa, Plecka, 2018).

The aim of this study is to diagnose the direction of influence of young people's religious involvement on three planes: their community activity, consent to religion's interference in the public sphere, and approval for the restrictive views of Catholic Church hierarchs on issues such as euthanasia, artificial contraception, homosexual relationships and in vitro fertilization. Individuals' attitudes and views in these areas are the expression of their social openness. Civil engagement requires certain communal competence, the desire to cooperate, voluntary action for the benefit of other people, and indirectly also trust. Including in the analysis the approval for religion's interference in the public sphere results from the specific relationship between those planes in Poland. Firstly, apart from religious functions, the Catholic Church has always been a strongly politicized institution. The alliance between the throne and the altar gave it a privileged position in social relationships. Secondly, in the past, Church hierarchs came from the most prominent aristocratic families, often implementing in their activity the political strategies of princely or magnate families. Accepting the holistic interference of religion in politics will be an expression of a less open attitude of individuals who pursue to close the social and political space in the framework of familiar and stable system of religious values. Catholic Church hierarchs' views on issues such as euthanasia, artificial contraception, homosexual relationships and in vitro fertilization is very restrictive

${ }^{1}$ Activation or withdrawal generated by religious engagement results from the nature of religious system, which is based on values. Most theories assume that values serve the motivational function and involve a high emotional load. Referring to classic authors, Milton Rokeach (1973) identifies values as beliefs with an emotional aspect which affect one's choice of goals and ways of achieving them. According to Shalom Schwartz (1992, p. 4), values are concepts or beliefs which refer, not only to specific situations, but to ultimate states or behaviors. Values determine the choice or evaluation of behaviors and events and are organized in accordance with their relative importance. Many empirical studies analyze the relationships between values (including the religious system with its different expressions) and social attitudes and behaviors, evidencing a significant relationship between them. 
and regularly referred to in public discussions in Poland. The support for these views will be an expression of a closed attitude, contradicting liberal values.

The group defined in the presented study is young Silesians from Sląskie (Silesian) Province. Many studies prove that religion is regarded as one of the fundamental values and the core of Silesians' identity (Bukowska-Floreńska, 2007; Świątkiewicz, 2007; Swadźba, $2012,2014 \mathrm{~A})$. The religiosity of each individual develops in a specific environment, where a specific culture and a specific religion co-occur. Empirical research shows that the family environment has the fundamental influence on the shaping of a young person's religiosity. This influence is associated with the principles upheld in the family, relationships between its members based on these principles, the prevalent views of God, and the family atmosphere (Stepulak, 2010, pp. 207-236; Zaręba, 2010, pp. 14-16; Zych, 2012, p. 120). In the context of the study, it is interesting whether the classic values pointed out in literature play an important role in the lives of young Silesians too, activating and moderating their sociopolitical attitudes. Interest in the young generation of Silesians is also connected with the new trends described in literature. For example, interesting results emerge from the report from the nationwide study IRCENTER (carried out with the CAVI method), which shows how the Silesian national identity is currently perceived by the youngest Silesians as compared to older residents of the region. For people under 24 years of age, Silesian national identity is mostly associated with the "go-ahead" attitude, "the tendency to have fun" or "creativity", while those aged $60+$ point to "industriousness","respect for history and tradition","frugality" and "hospitality" as the appreciated Silesian qualities. Other age groups express ideas similar to those mentioned by the oldest group (IRCENTER, 2015). These trends are related to the transformations occurring in Silesia. "For young people, cultural transformation in Silesia is a kind of game played with the Silesian tradition, while for Silesia, it means the radical de-Silesianization of the town and the whole region"' (Oslislo-Piekarska, 2015, p. 21). Many young Silesians have had the experience of traveling or working abroad, know Europe better, and use it as a model to imitate. For them, the world is an inspiration to change and improve the local conditions. They often prefer to adopt the local and regional identification rather than the national one, and at the same time, they regard themselves as Europeans (Oslislo-Piekarska, 2015, p. 59).

\section{(De-)motivational Aspects of Religious Engagement}

On the one hand, researchers prove that religious engagement strengthens social and communal competence. The religious factor plays an important role in linking religious axiology with social values (Leege, 1993, pp. 3-26) and in socialization functions of religious institutions (Greenberg, 2000, p. 377-394; Jones-Correa \& Leal, 2001, p. 751-770). Research results show that religion mobilizes people to engage in social and political activity, determining their engagement and ways of its expression (Musick, Wilson, 2008, p. 279; Aghazadeh, Mahmoudoghli, 2017). In the USA, religiosity and regular participation in church services 
correlated with higher indices of voter turnout (Miller, Wattenberg, 1984, pp.301-317; Verba, Schlozman, Brady, 1995, p. 434; Wuthnow, 2003, pp. 423-442), political interests, voluntary membership in organizations (Smidt, 1999, pp. 185-187; Ruiter, DeGraaf, 2006, p. 197), or voluntary and charity activity (Greeley, 2001; Ruiter, DeGraff, 2006; Putnam, Campbell, 2010). In addition, active participation in church community contributed to the improvement of individual social competence, communication and organizational skills (Verba, Schlozman, Brady, 1995, pp. 320-330, 378, 444; Smidt 1999, p. 178). A Canadian study, in turn, proves stronger relations between religiosity and regular participation in church services and activity in voluntary organizations, charity work and voluntary work (Gidengil, Blais, Nadeau, 2004, p. 161; Bowen, 2004; Reed, Selbee, 2000, pp. 571-592; Smidt, 1999). In Poland research carried out as part of the General Polish Electoral Study quite consistently shows positive relationships between participation in religious practices and the likelihood of taking part in elections (Cześnik, 2009, p. 26).

An opposite view stresses the possibility that religious activity may reduce the level of social openness (Wuthenow, 1999, pp. 331-363), the competitive character of citizens' trust in their own religious group at the expense of general social capital (Uslaner, 2000, pp. 569-590; Daniels \& der Ruhr, 2010; Storm, 2015, pp. 14-29), or even the fact that religious activity lowers citizens' knowledge and social competence (Scheufele, Nisbet, Brossard 2003, pp.300-324). Two kinds of relationship can be identified within the demobilization role of religion for social participation (Turska-Kawa, Wojtasik, 2014, pp. 6-23). First, the sphere of religion will always be competitive to social activity, including political activity, and as a result it will shift individuals' interest toward religious issues. This will happen because of a limited amount of resources the citizens can allocate to their activity, and engagement in the life of the Church will reduce the possibility of activity on other planes of social activity (Wuthnow, 2003). In addition, high trust in religious institutions may lower trust in other institutions, and thus also the general social capital (Uslaner, 2000). The other direction of the analysis refers to the level of individuals' religious dogmatism, on its basis formulating conclusions about a negative influence of extreme doctrinal engagement on social participation. On the one hand, this results from the relationship between extreme religious engagement and the frequency of participating in religious rites, and on the other hand, from the negative influence of membership in Church institutions on engaging in secular institutions activity (Scheufele, Nisbet, Brossard 2003, pp. 318-319). Dietram A. Scheufele, Matthew C. Nisbet and Dominique Brossard (Ibidem, p. 319) point out that strong religious engagement co-occurs with lower political competence and sense of efficacy in this area.

Research also shows that religiosity may generate contradictory attitudes at the same time. On he one hand, it generates pro-social attitudes (Norenzayan, Shariff 2008; Preston et al., 2013), mainly directed at the members of one's own religious group and aggressive toward "outgroups", especially those that really or symbolically threaten religious and moral values (Batson et al., 1999). At the same time, some data demonstrates that in the case of negative attitudes toward out groups religion can be a factor preventing actual aggression 
by referring to values such as e.g., the need of self-control regarding negative emotions or impulsive acts (McCullough, Willoughby, 2009).

\section{Religiosity of Silesians}

The boundaries of Silesia have been modified many times. Changes in the state affiliation of the area and the resulting territorial transformations definitely had an influence on the socio-economic development of the region and contributed to the fusion of different national, political, religious and economic systems (Heffner, Solga, 2012, p. 128). Merging influences of other nationalities and cultures, mostly Czech, German and Polish, generated the Silesian identity specific for some of the residents. Some researchers studying the Silesian identity observe that it is a blend of different cultures and influences; however, the majority of scholars define the core of Silesian identity using three essential values: work, family and religiosity.

Hence, religiosity can be considered as a core element of Silesians' identity. The stable position of this value was shaped as early as in the time of industrialization, when religion integrated, strengthened and propagated culture. It was a kind of protective umbrella for strange influences. Thanks to the work of Catholic priests and their engagement in protecting Polish identity, paradoxically laicization processes did not affect Silesia as much as they affected many other places in Europe in the time of rapid industrialization and urbanization. In the real socialism period, Silesians' bond with the Catholic Church did not weaken, either. Also, the turbulent 1980s only consolidated Silesians' religious attitudes. The period of system transformation and socio-economic changes affected the lives of the residents in different ways but they did not weaken their religiosity (Swadźba, 2012).

Research carried out since the beginning of the $21^{\text {st }}$ century proves that despite many influences and impacts of other cultures or competitive ideologies and values, religion still plays an important role in the life of Silesians. The study by Agata Zygmunt (2008, p. 58-59) shows that for the vast majority of Silesians religion is very important (46.1\%) or quite important (36\%). The importance of religion in the life of Silesians is proved by $94.8 \%$ self-declarations of Catholic Church affiliation (Górny, 2008, p. 106). In another study, this referred to 95\% respondents (Świątkiewicz, 2007, pp. 37-53).

As pointed out by Urszula Swadźba (2014A, p. 62), religious values have special importance in smaller communities where materialist values dominate and the impact of institutional religiosity is still strong. However, the author points out that although its role is still important, the strength of religiosity is decreasing. Laicization tendencies, referring to a part of the middle-aged and young generations, are clear. Religiosity is diversified between regions, even in originally Silesian areas. It is stronger in areas where native residents prevail, and weaker wherever migration processes are active (Swadźba, 2012, pp. 345-392).

One expression of the liveliness of Silesian religiosity is religious practices. They are part of the culture of Silesia, and participating in them is proof of belonging to a religious community. 
High participation of nearly all individuals declaring Catholic Church affiliation refers to onetime practices (baptism 98.0\%, the First Holy Communion 97.6\%). The majority of believers in smaller Silesian communities also take part in regular practices. But in big cities the members of the young generation, especially men, are departing from institutional religiosity. Daily practices have weaker results. The findings of studies carried out in bigger cities show that the residents more and more often prefer other, more satisfactory forms of activity on Sundays, such as an outing or shopping at the supermarkets (Swadźba, 2012; Swadźba, 2014B, p. 36).

\section{Research Model}

The research model involves one independent variable and three dependent variables in separate single-variable models. The independent variable is religious engagement. Religiosity, understood as a complex structure, including views, beliefs and values concerning a religious subject, contributes to specific behaviors: religious practices (Gosztyła, 2010). Religiosity manifests itself in specific actions; without them it would be a kind of world view, philosophy or ideology (Mariański, 2017, p. 244). In the presented study, we verified the scope of this predictor explaining the variation of variables connected with the attitudes and engagement of young Silesians in the political sphere: (1) community engagement, (2) approval for religion's interference in the public space, and (3) accepting Catholic Church hierarchs' views on problems such as artificial contraception, homosexual relationships, euthanasia and in vitro fertilization. All these variables are the expression of the individual's position in the continuum of socially closed vs socially open attitude.

The study was oriented at young people due to the fact that, on the one hand, they are the most strongly exposed to active liberalization and individualization trends in Europe, and on the other hand, they come from families that are historically and socially rooted in an environment where religious values play a fundamental role. The study was carried out among Silesians, where religion is regarded as one of the basic values and the core of the Silesian identity. Their attitudes and opinions are important from the point of view of their further participation in the civic and political community.

The relationships between religious engagement and community activity presented in source literature have at least two opposite directions. The first approach stresses the mobilization role of religious engagement for social and political activity, enhancing its active participation in behaviors oriented at the community. Another view, however, shows religious engagement as a factor weakening social and political activity, lowering trust and generally being an encumbrance for the social capital. The study is oriented at diagnosing the direction and level of this relationship among young Silesians. The other dependent variable in the model is the perception of the legitimacy of combining the religious sphere with the public one. This issue is specific for Poland, resulting from the chosen discussions and directions of activity taken by politicians, also in electoral programmes. I am interested in the level of approval for a fusion of these two spheres among young people who are about to obtain 
their active voting right. The third variable is the perception of legitimacy of the opinions of Catholic Church hierarchs on issues connected with values that are also widely discussed in the political sphere, such as the attitude to euthanasia, homosexual relationships, artificial contraception or in vitro fertilization. It seems that these are specific problems which concern young people and arouse their interest. The strong presence of religion in the public sphere of Poland also means that these problems are often the object of political discussions in which the members of the sacral circle widely express their views, opposing liberal values. In this study I did not diagnose the values upheld by young people but their opinions on the legitimacy of the general views of Church hierarchs on the discussed problems. We may presume that young people can personally be open to liberal values, but their attitude will be modified by the opinion of the Church, which is more valuable for them.

In the study, the mentioned relationships were given the form of the following research questions:

Is religious engagement a significant predictor of young Silesians' community engagement of young Silesians?

Is religious engagement a significant predictor of young Silesians' attitudes to the approval of religion's interference in the public sphere in Poland?

Is religious engagement a significant predictor of attitudes accepting Catholic Church hierarchs'views on problems such as artificial contraception, euthanasia, homosexual relationships and in vitro fertilization?

\section{Methodology}

The study was carried out among young people aged 16-19, upper secondary school students from Śląskie Province. The respondents were selected using stratified random sampling, where the strata were Częstochowa, Bytom, Sosnowiec, Gliwice, Katowice, Tychy, Rybnik and Bielsko-Biała sub-regions, and the sampling involved two stages: the choice of school and of class. Given the diverse ethnic structure of Silesian Province residents, a purposeful criterion was used in the final sampling. The questionnaire included the question "Do you regard yourself as a Silesian?", which served as the ultimate verification of the inclusion of participants. Only the questionnaires filled in by people who met all the criteria (the random and purposeful ones) were analyzed. Based on the purposeful question, 23 people were excluded from the sample. Finally, the sample was composed of 291 women (51.3\%) and 276 men (48.7\%).

Several indicators were introduced in the study, whose analysis was oriented at finding the answers to the research questions.

The religious engagement indicator was constructed on the basis of several statements concerning religious activity in different areas: (1) regular participation in Sunday holy mass, (2) prayer (individual conversation with God), (3) regular use of the confession sacrament, 
(4) regular use of the holy communion sacrament. The cafeteria was made up of Likert scale responses (I strongly agree, I agree, hard to say, I disagree, I strongly disagree). The reliability of the scale, determined with Cronbach's alpha coefficient, was .62.

The community engagement indicator was constructed as a four-item scale (I actively support the activity of non-governmental organizations (foundations, associations etc.); I participate in charity activities, I help my neighbors; I am interested in the issues connected with my town/commune). The cafeteria was made up of Likert scale responses (I strongly agree, I agree, hard to say, I disagree, I strongly disagree). The reliability of the scale, determined with Cronbach's alpha coefficient, was .84 .

The religion in the public sphere indicator was oriented at the diagnosis of support for the interference of the religious sphere in the public one on the basis of several important areas: (1) the perception of the words concluding deputies' oath: "So help me God", (2) the presence of religion as a compulsory subject at school, (3) expecting the President of the Republic of Poland to be Catholic, (4) the presence of the cross in the Sejm hall, (5) expecting politicians to uphold Catholic values. The reliability of the scale, determined with Cronbach's alpha coefficient, was .76.

The approval for the Church's views indicator was oriented at diagnosing the level of young Silesians' support for Catholic Church hierarchs' views on problems such as: (1) euthanasia, (2) in vitro fertilization, (3) same-sex relationships, (4) access to artificial contraception, (5) the use of the "morning after" pill. The cafeteria was made up of Likert scale responses (I strongly agree, I agree, hard to say, I disagree, I strongly disagree). The reliability of the scale, determined with Cronbach's alpha coefficient, was .71.

\section{Results}

Table 1 presents descriptive statistics for all the variables by sex. Generally, in terms of religious engagement and religion in the public sphere, the mean values are below the average. In terms of approval for the Church's views and community engagement, the values are significantly higher. With regard to sex, significant differences were only found in community engagement. Women represent a significantly higher level of community engagement than men: $\mathrm{t}(511.955)=4.423 ; \mathrm{p}<.001$.

Table 1. Descriptive statistics of the analyzed variables by sex

\begin{tabular}{|c|c|c|c|c|c|}
\hline Variable & Sex & Mean number & & $\begin{array}{l}\text { Standard } \\
\text { deviation }\end{array}$ & $\begin{array}{c}\text { Standard } \\
\text { error of mean }\end{array}$ \\
\hline \multirow{2}{*}{$\begin{array}{l}\text { Religious } \\
\text { engagement }\end{array}$} & Woman & 291 & 2.84 & 1.05364 & .06177 \\
\hline & Man & 276 & 2.69 & 1.01066 & .06106 \\
\hline \multirow{2}{*}{$\begin{array}{l}\text { Community } \\
\text { engagement }\end{array}$} & Woman & 291 & 4.09 & 688299 & .04004 \\
\hline & Man & 276 & 3.80 & .90171 & .05428 \\
\hline \multirow{2}{*}{$\begin{array}{l}\text { Religion in the } \\
\text { public sphere }\end{array}$} & Woman & 291 & 2.91 & .90274 & .05292 \\
\hline & Man & 276 & 2.81 & .86771 & .05261 \\
\hline
\end{tabular}




\begin{tabular}{llcccc}
\hline Variable & Sex & Mean number & & $\begin{array}{c}\text { Standard } \\
\text { deviation }\end{array}$ & $\begin{array}{c}\text { Standard } \\
\text { error of mean }\end{array}$ \\
\hline $\begin{array}{l}\text { Accepting the } \\
\text { Church's views }\end{array}$ & Woman & 291 & 3.48 & .94210 & .05523 \\
\cline { 2 - 6 } & Man & 276 & 3.37 & .92494 & .05567 \\
\hline
\end{tabular}

Then, linear relations between the analyzed variables were verified. Table 2 presents Pearson's $r$ correlation coefficients for the independent variable and the dependent variables.

Table 2. The table presents the relationships between the dependent and independent variables of the model

\begin{tabular}{lc}
\hline & Religious engagement \\
\hline Community engagement & -.06 \\
\hline Religion in the public sphere & $.54^{* *}$ \\
\hline Accepting the Church's views & $.44^{* *}$ \\
\hline
\end{tabular}

${ }^{\star *}$. Correlation significant at the level of 0.01 (bilaterally).

The verification of the relationship between the independent variable and dependent variables showed a significant relationship of the predictor only with religion in the public sphere and accepting the Church's views. The relationship between religious engagement and community engagement proved to be statistically insignificant, which meant there was the reason for performing univariate regression analysis for this part of the model.

Next, regression analysis was performed in single-variable models. For religious engagement as a predictor of religion in the public sphere, $\mathrm{R}$ squared statistic was obtained at the level of .30, which means that this variable explains $30 \%$ of variance. This model is statistically significant, the value of $F$ statistics is $F(1 ; 561)=242.115 ; \mathrm{p}<.001$ (Table 3 ). Religious engagement also proved to be a significant predictor of the approval for the vies expressed by Catholic Church hierarchs concerning problems such as euthanasia, artificial contraception, homosexual relationships and in vitro fertilization; $\mathrm{F}(1 ; 563)=135.019 \mathrm{p}<.001$. In this model, $\mathrm{R}$ squared value was .193, which means that religious engagement explains $19.3 \%$ of variance of the approval for the views Church hierarchs (Table 3 ).

Table 3. Estimation of regression coefficients in single-variable models with the predictor of religious engagement

\begin{tabular}{|c|c|c|c|c|c|}
\hline & \multicolumn{2}{|c|}{ Non-standardized coefficients } & \multirow{2}{*}{$\begin{array}{c}\begin{array}{c}\text { Standardized } \\
\text { coefficients }\end{array} \\
\text { Beta }\end{array}$} & \multirow[t]{2}{*}{$\mathbf{T}$} & \multirow{2}{*}{$\begin{array}{c}\text { Signifi- } \\
\text { cance }\end{array}$} \\
\hline & B, D & Standard error & & & \\
\hline \multicolumn{6}{|c|}{ Religion in the public sphere } \\
\hline (constant) & 7.764 & .448 & & 17.313 & .000 \\
\hline Religious engagement & .482 & .031 & .549 & 15.560 & .000 \\
\hline \multicolumn{6}{|c|}{ Views of Catholic Church hierarchs } \\
\hline (constant) & 22.935 & .497 & & 46.123 & .000 \\
\hline Religious engagement & .398 & .034 & .440 & 11.620 & .000 \\
\hline
\end{tabular}




\section{Discussion and Conclusions}

The aim of the presented study was to diagnose the role of religious engagement in the social attitudes of young Silesians, operationalized on the continuum of closeness vs openness in three areas: (1) community engagement, (2) approval for religion's interference in the public space, and (3) accepting Catholic Church hierarchs' views on problems such as euthanasia, artificial contraception, homosexual relationships and in vitro fertilization.

First of all, the predictor of young Silesians' religious engagement is below the mean value of the scale used in the study. Thus, weaker religiosity of Silesians follows the nationwide trend diagnosed since the 1990s. In this tendency, the proportion of believers is slowly decreasing, while the proportion of indecisive ones and unbelievers is growing (Młodzież, 2016). In addition, a gradual decrease in the level of youths' participation in masses, services and other religious meetings is observable (e.g., weekly participation has dropped from $55 \%$ in 1996 to $32 \%$ in 2016). In 2016, in comparison to 2013, adolescents' attendance at religion lessons at school dropped by 11 percentage points in rural areas, by 17 percentage points among small towns and by as much as 24 percentage points in big cities. The latest report by the Public Opinion Research Center (CBOS) "Młodzież 2016" shows that currently, young Poles are less willing to establish families and live in accordance with the principles of their religion and more willing to pursue professional successes. A study by Janusz Mariański (2017, p. 226) proves that religion can no longer be regarded as subjectively important for a part of Polish youths; it no longer belongs to the world they experience. Irena Borowik (2016, p. 11-12) points to the following symptoms of changes in religiosity in adolescent circles: a) lower participation in Sunday services, neglecting confession and the holy communion, fewer new priests and monks; b) the model of religiosity of young women becoming similar to that of young men. The indices of religiosity of young women under the age of 30 have been decreasing more quickly than those of men of the same age, which may in the future affect the processes of religious socialization in the family; c) adolescents engage in the activity of atheistic, rationalistic and humanistic associations more often that adults do; sometimes they openly protest against the practices of the Catholic Church that make it difficult to leave it completely; d) young people have a critical view of the Church as an institution, the clergy, as well as religious instructors, pointing out their reluctance to engage in discussions, providing ready solutions, and the rigidity of the whole religious message.

Low religious engagement among young Silesians, i.e. people coming from the environment where religiosity is considered as one of the most important values, generates new exploration questions. We found out that despite the stable thesis that the closest environment (the family) has the greatest impact on the development of customs and upholding religious traditions, young Silesians do not display high religious engagement. This may result from two things, which need to be studied more thoroughly. First, perhaps the core of the identity of Silesians should be verified anew, allowing to separate values from 
religious principles in Silesian families? Second, perhaps the competition between religious values and modern/liberal values is won by the latter ones, which have an equally strong influence e.g., through the media as through the family? Maybe Silesian religiosity is more and more subject to processes of individualization and pluralization. According to Janusz Mariański (2006, p. 12): "Polarization into the private sphere and the public sphere leads to the loss of importance of religion in social dimensions. It is becoming the matter of choice, preference and personal taste, and in the public sphere it is losing its general normative power. Religiosity that is in a way filtered through individualized subjectivity and personal pursuits becomes relative, loses the clear church boundaries and especially the authoritarian aspects. These individualization processes often mean the departure from institutionalized orthodoxy toward the selectivity or privatization of religious beliefs."

Three research questions were posed as part of the research procedure. The first one referred to diagnosing the significance of religious engagement in community engagement of young Silesians. The analysis did not show any significant relationships between the variables. It is worth stressing, however, that community engagement of the respondents was relatively high, especially as compared with the lower degree of religious engagement. It was significantly higher for women (4.09) than for men (3.79). In comparison to the results of other nationwide studies, Silesian youths represent a high level of engagement. Research shows that against the background of other nationalities, Polish youths are the most optimistic in their perception of social problems, but are the least willing to engage in activity for the benefit of the society (Krzywosz-Rynkiewicz, Zalewska, 2010). Only one tenth of upper secondary school students declare that being useful for others is among their important life goals (Boguszewski, Kowalczuk, 2014). Young people display low engagement in regular activity of non-governmental organizations and voluntary organizations, although they are likely to take part in occasional projects (Siegień, 2010). A more recent study by Beata Krzywosz-Rynkiewicz and Anna M. Zalewska (2015) shows that against the background of other nations, Polish youths display stronger passive citizenship (the sense of patriotism, respect for national symbols and loyalty to the state) and lower engagement in politics; they are slightly less willing to act toward change, although in comparison to other nationalities they are more socially involved.

In the study by Krzywosz-Rynkiewicz and Zalewska (ibidem), four groups of young Poles were identified. The first one is Political Activists, for whom politics is an element of strong engagement and who have the sense of national affiliation, want to participate in elections and act for the benefit of the community. They are a group with high civic potential. Unfortunately, its size decreases with age and at the age of 18 the group is rather small. The second one is Apolitical Activists, who also represent an above-average level of engagement but are uninterested in political issues. The size of this group only slightly decreases with age, and it is the largest identified group of young people. The third group, Alienated Politicians, apart from politics display little engagement in other activities. They have a poor civic potential. The size of the group also decreases with age. The last group, 
Alienated Individualists, is made up of people with the lowest level of community activity and above-average engagement in their own development. Their number grows with age. The study showed that eleven- and fourteen-year-olds declare a much higher level of readiness to act for the benefit of their community and engage in broadly understood politics. The closer they are to the moment of obtaining active voting right, the lower is their level of political engagement.

The second question referred to the diagnosis of significance of religious engagement for young Silesians' approval for religion's interference in politics. The analysis showed significant relationships between the variables: religious engagement explains $30 \%$ of the variable religion in the public sphere. This means that religious engagement is a significant predictor of the approval for religion's interference in the political sphere. The study confirms the findings of the CBOS report (Młodzież,2016), which show that $27 \%$ of people who often engage in religious practices are of the opinion that the Catholic Church should have a special impact on law establishment. People who practised more often also displayed a higher level of support for organizations such as the National Radical Camp and All-Polish Youth, extremely rightist political groups for young people which propagate nationalistic values. Another report (CBOS, 2015A) referring to the society as a whole shows almost universal support for the presence of crosses in public buildings, no objection to religion lessons at school and support for the religious character of military oath. Besides, the respondents are not against the consecration of public utility buildings and other places by priests or against priests' and bishops' participation in state celebrations. Approximately three fourths of the respondents declare they have nothing against priests appearing on public TV. However, in the case of the Church expressing its views on acts adopted by the Sejm or priests telling people how to vote in elections, the situation is the opposite: the majority do not approve of this. Basically, attitudes approving of religion in the political space are more often manifested by people who are believers or even deeply devout and who regularly take part in religious practices.

The aim of the third question was to diagnose the significance of religious engagement for the level of young Silesians' acceptance of Catholic Church hierarchs' views on problems such as euthanasia, artificial contraception, homosexual relationships and in vitro fertilization. Religious engagement proved to be a significant predictor of approval for the views expressed by Catholic Church hierarchs on the mentioned issues: religious engagement explains $19.3 \%$ variance of the accepting the views of Church hierarchs.

This is consistent with research results presented in source literature, quite consistently finding that higher religious engagement is related to the approval for values connected with the social order and objection to values referring to changes and the questioning of the established rules (e.g. Saroglou, Delpierre \& Dernelle, 2004; Roccas, 2005; Brzozowski, 2007). This approach may result from the principles of most major religions of the world, postulating self-control and restraint in pursuing pleasures and recommending moderation at the level of biological life. In a CBOS study, three-fifths of the respondents approved of 
Church representatives expressing their views on subjects concerning morality and social life (CBOS, 2015B).

The results of the current study confirm that religious engagement is a significant predictor of a closed social attitude in two out of three areas proposed in the model. It significantly explains the approval for religion's interference in the public sphere. Higher religious engagement promotes the desire to incorporate the approved religious principles into the secular space. This may result from fear of liberalization of this apace and popularization of values threatening the individual. It may also prove the pursuit of higher sense of security, which will definitely be stronger if one is surrounded by familiar and predictable values. Religious engagement is also a significant predictor of acceptance of Catholic Church hierarchs' views on problems such as artificial contraception, euthanasia, homosexual relationships and in vitro fertilization. It is the expression of consistency of the religious attitude, which agrees with the Church's teaching. Interestingly, relationships between religious engagement and community activity of young Silesians were not confirmed. This opens a new space for the search of determinants of this activity in other areas, especially that a strong element of community virtue was diagnosed in this group. The contemporary social transformations go in different directions and have different intensity. Traditions concerning religion are being modified all the time, and thus, perhaps new forms of what is religious and spiritual are developing. Young Silesians do not escape nationwide liberalization tendencies, although in their case the tendencies progress more slowly.

\section{References}

Aghazadeh, J., Mahmoudoghli, R. (2017). "Religion and political engagement". Cogent Social Sciences, 3, 1-8. DOI: https://doi.org/10.1080/23311886.2017.1368109.

Batson, D. C., Floyd, R. B., Meyer, J. M., Winner, A. L. (1999). "And who is my neighbor?: Intrinsic religion as a source of universal compassion". Journal for the Scientific Study of Religion, 384, 445-457. DOI: $10.2307 / 1387605$.

Blais, A., Gidengil, E., Nevitte, N. (2004). "Do (Some) Canadian Voters Punish a Prime Minister for Calling a Snap Election?”. Political Studies, 52(2), 307-323. DOI: https://doi.org/10.1111/j.14679248.2004.00481.x.

Boguszewski, R., Kowalczuk, K. (2014). “Aspiracje, dążenia i plany życiowe młodzieży”. In Młodzież 2013 (6-21). Warsaw: CBOS, Krajowe Biuro ds. Przeciwdziałania Narkomanii.

Borowik, I. (2016). "Przemiany religijne w Polsce na tle transformacji w Europie Środkowo Wschodniej i globalizacji”. In I. Borowik, A. Górny, W. Świątkiewicz (Eds.), Globalny i lokalny wymiar religii. Polska w kontekście europejskim (7-16). Kraków: Zakład Wydawniczy NOMOS.

Bowen, P. (2004). "Investing in Canada: Fostering an Agenda for Citizen and Community Participation". sportmatters.ca. Retrieved from: www.sportmatters.ca.

Brzozowski, P. (2007). Wzorcowa hierarchia wartości. Lublin: Wydawnictwo UMCS.

Bukowska-Floreńska, I. (2007). Rodzina na Górnym Śląsku. Katowice: Wydawnictwo Uniwersytetu Śląskiego. 
CBOS. (2012). “Społeczne postawy wobec wyznawców rożnych religii”. Komunikat z Badań, BS/130/2012. CBOS. (2015A). “Boskie i cesarskie, O stosunkach między państwem i kościołem”. Komunikat z Badań, 48. CBOS. (2015B). “Kanon wiary Polaków”. Komunikat z Badań, 29.

Cześnik, M. (2009). Partycypacja wyborcza Polaków. Warsaw: Insytut Spraw Publicznych.

Górny, A. (2008). “Religijność śląska a procesy sekularyzacyjne”. In U. Swadźba (Ed.), Śląski świat wartości.

Katowice: Wydawnictwo Gnome.

Gosztyła, T. (2010). Rodzinne uwarunkowania dojrzałej religijności młodzieży. Lublin: Wydawnictwo KUL. Greenberg, A. (2000). "The Church and the Revitalization of Politics and the Community". Political Science Quarterly, 115(3), 377-394. DOI: 10.2307/2658124 https://www.jstor.org/stable/2658124.

Heffner, K., Solga, B. (2012). “Granice Śląska - granice na Śląsku. Ewolucja i współcesne wymiary”. In R. Gładkiewicz, T. Sołdra-Gwiżdż, S. Szczepański (Eds.), Granice Śląska w interdyscyplinarnej perspektywie (47-65). Opole-Wrocław: Wydawnictwo Instytut Śląski.

IRCENTER. (2015). Retrieved from: https://www.kp.pl/files/news/2991/Wyniki_badania_Co_to_znaczy_byc_Slazakiem.pdf.

Jones-Correa, M. A., Leal, D. L. (2001). “Political Participation: Does Religion Matter?”. Political Research Quarterly, 54(4), 751-770. DOI: 10.2307/449233 https://www.jstor.org/stable/449233.

Krzywosz-Rynkiewicz, B., Zalewska, A. M., (2015). "Aktywność obywatelska polskiej młodzieży w relacji do innych Europejczyków i w zależności od fazy adolescencji”. Psychologia Rozwojowa, 4(20), 11-23. DOI: $10.4467 / 20843879$ PR.15.019.4462.

Leege, D. C. (1993). "Religion and politics in theoretical perspective". In D. C. Leege, L. A. Kellstedt (Eds.), Rediscovering the religious factor in American politics (56-76). New York: M.E. Sharpe.

Mariański, J. (2006). Sekularyzacja a desekularyzacja w nowoczesnym świecie. Lublin: Wydawnictwo KUL. Mariański, J. (2013). Kościót katolicki w Polsce w przestrzeni życia publicznego. Toruń: Wydawnictwo Adam Marszałek.

Mariański, J. (2017). "Religijność maturzystów puławskich w okresie przemian”. Zeszyty Naukowe KUL, 2(238), 225-252.

Marszałek-Kawa, J., Plecka, D. (2018). Leksykon wiedzy politologicznej. Toruń: Wydawnictwo Adam Marszałek.

McCullough, M. E. Willoughby, B. L. B. (2009). "Religion, Self-Regulation, and Self-Control: Associations, Explanations, and Implications”. Psychological Bulletin 135(1), 69-93. DOI: 10.1037/a0014213.

Miller, A., Wattenberg, M. (1984). "Politics from the Pulpit”. Public Opinion Quarterly, 48(1B), 301-317. DOI: https://www.jstor.org/stable/2748625.

Młodzież 2016. (2016). Warsaw: Centrum Badania Opinii Publicznej.

Musick, M. A., Wilson, J. (2008). Volunteers: A Social Profile. Indianapolis: Indiana University Press.

Norenzayan, A., Shariff A. F. (2008). “The origin and evolution of religious prosociality”. Science 322(5898), 58-62. DOI: https://doi.org/10.1126/science.1158757.

Oslislo-Piekarska,Z. (2015). “Nowi Ślązacy. Miasto, dizajn, tożsamości”. sbc.org.pl. Retrieved from: https:// sbc.org.pl/Content/179084/Nowi\%20Slazacy_SBC.pdf.

Podczasik, M. (2014). “Rodzina i religijność jej dzieci a stosunek do wiary”. Family Forum, 4, 163-182.

Preston, J. L., Salomon, E., Ritter, R. S. (2013). "Religious Prosociality. Religion, personality, and social behaviour”. In V. Saroglou (Ed.), Religion, personality, and social behaviour (34-54). New York: Psychology Press.

Putnam, R. D., Campbell, D. E. (2010). American Grace: How Religion Divides and Unites States Us. New York: Simon and Schuster. 
Reed, P. B., Selbee L. K. (2000). “Distinguishing Characteristics of Active Volunteers in Canada”. Nonprofit and Voluntary Sector Quarterly, 29(4), 571-592.

Roccas, S. (2005). "Religion and values system”. Journal of Social Issues, 61(4), 747-759.

Rokeach, M. (1973). The Nature of Human Values. New York: The Free Press.

Ruiter, S., De Graaf, N. D. (2006). "National Context, religiosity and volunteering: results from 53 countries". American Sociological Review, 71, 191-210.

Saroglou, V., Delpierre, V., Dernelle, R. (2004). "Values and religiosity: A meta-analysis of studies using Schwartz's model”. Personality and Individual Differences, 37(4), 721-734. DOI: http://dx.doi. org/10.1016/j.paid.2003.10.005.

Scheufele, D. A., Nisbet M. C., Brossard, D. (2003). "Pathways to political participation? Religion, communication contexts, and mass media”. International Journal of Public Opinion Research, 21(3), 300-324. DOI: https://doi.org/10.1093/ijpor/15.3.300.

Schwartz, S. (1992). "Universals in the content and structure values: Theoretical advances and empirical tests in 20 countries”. Advances in Experimental Social Psychology, 25, 1-65. DOI: http://dx.doi. org/10.1016/S0065-2601(08)60281-6.

Siegień, W. (2010). “Action for change at a personal level”. In B. Krzywosz-Rynkiewicz, A. Zalewska, A. Ross (Eds.), Future citizens: $21^{\text {th }}$ century challenges for young people (265-282). Kraków: Impuls.

Smidt, C. (1999). "Religion and Civic Engagement: a Comparative Analysis". Annals of the American Academy of Political and Social Sciences, 565(1), 176-192.

Stepulak, M.Z.(2010). Relacyjny wymiar rozwoju osobowego w systemie rodzinnym. Lublin: Wydawnictwo KUL.

Storm, I. (2015). “Civic engagement in Britain: The role of Religion and inclusive values”. European Sciological Review, 31(1), 14-29. DOI: 10.1093/esr/jcu077.

Swadźba, U. (2014A). "Praca, religia, rodzina. Od wartości materialistycznych do postmaterialistycznych". Acta Universitatis Lodziensis. Folia Sociologica, 48, 53-66.

Swadźba, U. (2012). Wartości pracy, rodziny i religii - ciagłość i zmiana. Socjologiczne studium społeczności śląskich. Katowice: Wydawnictwo Uniwersytetu Śląskiego.

Swadźba, U. (2014B). “Śląskie wartości - praca, rodzina i religia: geneza, trwanie i zmiany”. Górnośląskie Studia Socjologiczne. Seria Nowa, 5, 22-41.

Świątkiewicz, W. (2007). “Kondycja rodziny śląskiej”. In W. Jacher, A. Klasik (Eds.), Zmieniające się oblicza regionu górnośląskiego (37-53). Katowice: Wydawnictwo Gnome.

Turska-Kawa, A., Wojtasik, W. (2014). "Religiosity and electoral participation: the case of Poland". Studia Methodologica, 38, 6-23.

Turska-Kawa, A., Wojtasik, W. (2017A). "Diversity of Roman Catholics in Poland and Their Socio-institutional Preferences”. Religio: Revue pro religionistiku, 1, 43-68.

Turska-Kawa,A., Wojtasik, W. (2017B). “Directiveness as a predictor Predictor of religious Attitudes”. Polish Sociological Review, 2(198), 189-201. DOI: 10.1007/s40806-017-0103-y.

Uslaner, E. C. (2000). "Producing and Consuming Trust”. Political Science Quarterly, 115, 569-590. DOI: https://doi.org/10.2307/2657610.

Verba, S., Schlozman, K. L., Brady, H. E. (1995). Voice and Equality: Civic Voluntarism in American Politics. Harvard, MA: Harvard University Press.

Wuthnow, R. (2003). “Overcoming Status Distinctions? Religious Involvement, Social Class, Race and Ethnicity in Friendship Patterns”. Sociology of Religion, 64(4), 423-442. DOI: https://doi.org/10.2307/3712334. Wuthnow, R. (1999). “Mobilizing civic engagement: The changing impact of religious involvement”. In 
T. Skocpol, M. P. Fiorina (Eds.), Civic engagement in American democracy (98-114). Washington: Brookings/Russell Sage.

Zalewska, A., Krzywosz-Rynkiewicz, B. (2010). “Optimism and readiness for citizenship activity”. In

B. Krzywosz-Rynkiewicz, A. Zalewska, A. Ross (Eds.), Future citizens: $21^{\text {th }}$ century challenges for young people (305-332). Kraków: Impuls.

Zaręba, S. H. (2010). Rodzina - religia - społeczeństwo. Warsaw: Wydawnictwo Uniwersytetu Kardynała Stefana Wyszyńskiego.

Zych, A. (2012). Pomiędzy wiarą a zwątpieniem. Kraków: Oficyna Wydawnicza IMPULS.

Zygmunt, A. (2008). “System wartości rybniczan”. In U. Swadźba (Ed.), Ślaski świat wartości. Katowice: Wydawnictwo Gnome. 